\title{
Challenges of natural resources management in India: Is it institutional Failure?
}

\author{
Thaware C. Kailas $\bowtie$
}

Received: 27.06 .2018

Revised: 21.08.2018

Accepted: 10.09.2018

\begin{abstract}
This paper brings out the issues of institutional failures and loss of valuable national resources at the cost environment and public health. Despite having several regulations, the illegal mining activities are rampant in many states of India under the influence of dishonest politicians, officials, and mining mafias, resulting over-exploitation of natural resources may affect public health, environment and future requirements of next generation. Moreover, illegal mining and overexploitation not only make adverse impacts on ecological balance, environment, biodiversity, water sources etc. but also influence the livelihood of the tribal people, living in backward regions and mining areas. Institutions usually play very significant role to rationalize human needs and reduce uncertainties in the society by establishing a stable structure to human interaction. However, now a days, institutions fails to carry out their duties and responsibilities. North argued that institutional change is a complicated process because the changes at the margin can be a consequence of changes in rules, in informal constraints, and in kinds and effectiveness of enforcement. Institutions are a guide to human interaction and determine the opportunities in the society. If an institution deviates from its principle, role, and duties, it generally fails to protect public resources. India has been a rich natural resource country and so, most of the natural resource constraints countries are keeping their eyes on the India's natural resources at cost of local's health, and environment. In context of India, minerals, forests and tribals are concentrated in the same geographical locations. So, any mining activity always disturbs ecology, biodiversity and people who live around. If mining activities are illegal, severity of impact has been much more. The recent illegal mining activities in iron and manganese ores in India made huge losses to the public exchequers in billions of dollars. Illegal miners plundered natural wealth at the cost of disturbing ecology, environment, and displacing poor and their livelihoods. It could not have happened without a strong nexus between illegal miners, and politicians and bureaucrats. As global demand for minerals increased, the prices rose sharply at international markets, particularly in China. As it happened, behaviour of mining mafias in India have changed spontaneously and entered into illegal mining activity. Natural resource depletion can destabilize livelihoods, negatively affecting ecosystems, and undermine peace and development. Exploitation of natural resources is a key factor in economic growth and development, and also one that can have serious negative environmental and socioeconomic impacts. The local mining mafia stretched their empire for private gain at the cost of public resources and reaped the real benefits in collusions with dishonest politicians and public officials, violating most of the environmental and biodiversity norms of natural resource conservation. Even, on exposing such kind of illegal activities in mining areas, the political leadership is engaged to cover up such activities.
\end{abstract}

Key words: mine, natural resources, exploitation

\section{Introduction}

Institution usually plays very significant role to rationalize human needs through devised methods under laws. It reduces uncertainties in the society by establishing a stable structure to human interaction. Institutions are the humanly devised constraints that structure human interaction (North, 1993). It reduces uncertainties in the society by establishing a stable structure to human interaction

\section{Author's Address}

Gokhale Institute of Politics \& Economics,(Deemed to be University), Deccan Gymkhana, PUNE, - 411004 (MS), India. E-mail.: kailash_thaware@rediffmail.com
(North, 1990). North further argued that institutional change is a complicated process because the changes at the margin can be a consequence of changes in rules, in informal constraints, and in kinds and effectiveness of enforcement. Institutions are a guide to human interaction and determine the opportunities in the society. If the institution is established under laws to protect the natural resources and deviates from its principle, role, and duties, it generally cannot protect public resources. Several evidences in 
mining sector from India proved that Institution has failed to protect resources without contributing a larger benefit particularly to vulnerable sections of society. If it is assumed that an institution functions an efficient way in management of resources, the society receives the higher benefits. With the initiative of United Nations (UN), the relationship between man and nature was brought closer. The concept of rational use of natural resources for present and future generation has been developed by its initiatives. The Stockholm declaration (UN Report,1972) endorsed the importance of natural resources and expressed its concern over indiscreet degradation. It appealed to world governments for safeguarding to benefit present and future generations through careful planning or management, as appropriate (principle-2). The Brundtland Commission (WCED, 1987) and Rio Earth Summit (UN Conference, 1992) also made the same appeals and so, most of the developed countries have devised plans for sustainable and rational use of their natural resources, including non-renewable minerals.

\section{Policy Change in Response}

As it happened, the prices of minerals increased sharply at international markets. The exploitation of natural resources is a key factor in economic growth and development, but will have serious negative environmental and socio-economic impacts (Cronin and Pandya, 2009). The race for searching new resources has begun and mostly developed countries are ahead to developing countries, which have abundant natural resource base. Consequently, the rate of exploitation of natural resources significantly increased in developing country to meet the demand of international markets. At the same time, developing countries have changed their mining policy as well. India also modified its national mineral policy in 1993 and then in 2008. This policy responded to increasing demand of minerals in the international markets (Ministry of Mines, 2008). However, while changing mineral policy, every political party in the governments- central and state have put forward its own agendas. This made desperately degradation of natural resource base of the country. Both wrong policy of the government and present institutional arrangement have contributed further to rapid degradation of resources.

\section{Entry of Private Players and Illegal Mining Activities}

The government opened up mining sector to the private players, who established influence in government offices and so, new relationship emerged between politicians and bureaucrats, and mining mafias. Those who exposed this relationship were either attacked with threatening of dire consequences or killed them. Illegal mining can be traced to globalization process and deficiencies in export and port regulations (Chandrasekhar, 2010). Common man, who lives in simple lifestyle, get affected by the unsustainable exploitation of resources, badly reshapes the livelihood of local people, particularly of tribals in backward regions of the country. Further, the competition among the local mining investors rose sharply, particularly those who turn to be as politicians or closely associated with political parties. They started extracting minerals illegally and made huge money out of it at the cost of loss to public exchequers. The public authority also failed to control the activities of illegal miners. The foreign investors also invested in mining sector as demand increased in international markets. The local mining mafias stretched their empire with foreign demand for minerals as well.

\section{Research Questions}

In view of these arguments, this paper examines the role of governments, Institutions, politicians, and private companies involving in mining sector for extracting minerals in various states. Now there are several questions regarding the relationship of mining mafias and rapid degradation of natural resources as;

- Does it happen because of weak institutional arrangements?

- Does it affect environment, health, biodiversity, eco-system, etc.?

- Does mining mafia influence the policy of the government in their favour?

- Will India lose its natural resources rapidly?

\section{Mining Sector in India}

Out of total 328.73 million hectare (mha) geographical areas of the country, $304.89 \mathrm{mha}$ is the reporting area. About $264.5 \mathrm{mha}$ is reported under agriculture, forestry, pasture and other biomass production, out of which total cultivable land is 183.5 mha. and net sown area is 
approximately 140.9 mha (CWC, 2006-07). The country has reported (Ministry of mines Report, 2010-2011) various important 87 minerals, which include 4 fuels, 10 metallic, 47 non-metallic, 3 atomics and 23 minor minerals (including building and other materials) and valuable natural resources, constituting vital raw materials for industries, which contribute for rapid economic growth and development of the country. Some of mineral are highly demanded at international markets as developed countries have made strategy to use their country resources rationally. Number of reporting mines in the country has declined either by stopping extraction of minerals or by exhausted resources. It shows that there are now limitations for expanding the mining. All mineral mines have declined from 3150 in 2008-09 to 2628 in 2010-11. Under metallic category, numbers have declined to 608 in 2010-11, while under non-metallic category declined to 1446. All these are indicating depletion of valuable resources (Table 1).

Out of total 9398 leased out mining, about 192 mines are operating above 500 ha. Areas, covering about 202 thousand ha. It constitutes about 41 per cent area of the total mining area. About 57 per cent mines (5345) operate on less than 10 ha. Areas, covering about 21 thousand ha. Land. It constitutes about 4 per cent. The major areas are covered by 20 to less than 500 ha (Table 2). These indicate all types of mining operation extract the minerals.

Table 1: Number of Reporting Mines

\begin{tabular}{|l|c|c|c|}
\hline Sector & $2008-2009$ & $2009-2010$ & $2010-11$ \\
\hline All Minerals* & 3150 & 2999 & 2628 \\
\hline Coal (including Lignite) & 574 & 700 & 674 \\
\hline Metallic Minerals & 719 & 1725 & 1446 \\
\hline Non-Metallic Minerals & 1857 & & 608 \\
\hline $\begin{array}{l}\text { *Excluding atomic minerals, petroleum (crude), natural gas (utilized) and minor minerals } \\
\text { Source: Annual Report 2010-11, Ministry of Mines, Govt. of India. }\end{array}$ \\
\hline
\end{tabular}

Table 2: Area wise Distribution of Mining Leases* In India

\begin{tabular}{|c|c|c|c|c|}
\hline $\begin{array}{l}\text { Frequency Group } \\
\text { area in Hects }\end{array}$ & $\begin{array}{l}\text { Number of } \\
\text { Mining Leases }\end{array}$ & $\begin{array}{l}\text { Percentage of } \\
\text { Total Leases }\end{array}$ & $\begin{array}{l}\text { Area in '000 } \\
\text { Hects. }\end{array}$ & $\begin{array}{l}\text { Percentage } \\
\text { Total Area }\end{array}$ \\
\hline All Groups & 9398 & 100 & 493 & 100 \\
\hline $0-10$ & 5345 & 56 & 21 & 4 \\
\hline $10-20$ & 948 & 10 & 14 & 3 \\
\hline $20-50$ & 1293 & 14 & 44 & 9 \\
\hline $50-100$ & 927 & 10 & 70 & 14 \\
\hline $100-200$ & 428 & 5 & 60 & 12 \\
\hline $200-500$ & 265 & 3 & 82 & 17 \\
\hline Above 500 & 192 & 2 & 202 & 41 \\
\hline
\end{tabular}

* Excluding Fuel, Atomic \& Minor Minerals

Source: Annual Report 2010-11, Ministry of Mines, Govt. of India. 
Out of 32 States/Union Territories), about 90.16 per cent was confined to 10 States (including offshore areas). Offshore areas constitute about 26.03 per cent in the national output in terms of value of mineral production in the country. Next Orissa stands in second position with a share of 9.63 per cent, followed by Andhra Pradesh (8.98 per cent), Rajasthan (7.93 per cent), Chhattisgarh (7.77 per cent), Jharkhand (6.54 per cent), Gujarat (6.40 per cent), Madhya Pradesh (4.83 per cent), Goa (4.37 per cent), Assam (4.13 per cent) and Karnataka (3.57 per cent) in the total value of mineral production. During 2009-10, the Public Sector continued to play a dominant role in mineral production accounting for 74.48 per cent or $1,19,385.86$ crore in the total value (Annual Report, 2010-11, Ministry of Mines, Govt. of India). Small mines, mostly in the private sector, continued to be operated manually either as proprietary or partnership ventures. The country continued to be wholly or largely self- sufficient in minerals which constitute primary mineral raw materials to industries, such as, thermal power generation, iron \& steel, ferro-alloys, aluminum, cement, various types of refractories, china clay-based ceramics, glass, chemicals like caustic soda, soda ash, calcium carbide, titania white pigment, etc.

\section{Mining Regulations}

The enactment of the Mines and Minerals (Regulation and Development) Act, 1948 made uniform rules for miners and government as well. It was the first legal framework in independent India for the regulation and development of mines. During the same time, Indian Bureau of Mines (IBM) was set up in March 1948 as the main regulatory agency for monitoring and supervising mining activity in the country. When the Constitution became effective on 26 January 1950, the legislative powers of the Central government and the state governments have been clearly defined. The seventh schedule (entry 54 of List I) of the Constitution has empowered the Central government to regulate mining activities and the development of minerals. Entry 23 of List II has empowered the state governments to frame rules and regulations in respect of mining activities and mineral development, subject to the provisions of List I. The Industrial Policy Resolution, 1956 (IPR) has classified major minerals such as coal, lignite, mineral oils, iron ore, copper, zinc, atomic minerals, etc. in Schedule A, exclusively reserved for the public sector, and minor minerals in Schedule B, in which the private sector was allowed to participate in mining activities along with the public sector. The government framed the Mines and Minerals (Regulation and Development) Act, 1957 for the regulation of mines and development of minerals, applicable to all minerals except mineral oils. Under this Act, Mineral Conservation and Development Rules (MCDR) 1958 and Mineral Concession Rules (MCR), 1960 have been framed. The MCR deals with the major minerals and the state governments are free to frame their own rules for mineral concessions with respect to minor minerals. Act and rules have been amended several times to consolidate the control over the minerals, accommodate Foreign Direct Investment (FDR) till February 2006, the mining sector was opened up to 100 per cent FDI. The New Mineral Policy of 2008 simplify the procedures for grant of mineral concessions, develop a sustainable framework for optimum utilisation of the country's natural mineral resources for the industrial growth in the country and at the same time improving the life of people living in the mining areas which are generally located in the backward and tribal regions of the country.

\section{Sustainable Development Framework (SDF) for Mining Sector}

The sustainable development framework devised guidelines, rules and principles for how to conserve, develop, and use rationally the renewable and non-renewable natural resources. The same frame work was also developed for the mining sector in India. It devised that "Mining that is financially viable; socially responsible; environmentally, technically and scientifically sound; with a long term view of development; uses mineral resources optimally; and, ensures sustainable post-closure land uses. Also one based on creating long-term, genuine, mutually beneficial partnerships between government, communities and miners, based on integrity, cooperation and transparency"(Ministry of Mines , May, 2012). This comprehensive definition of the Sustainable Development Framework (SDF) incorporates not only regulatory requirements, but goes beyond that and recommends practices and best in class aspects to address the challenges of sustainable development more fully. It provides a path towards 
achieving sustainable development aided by guidance steps, measurable outcomes and reporting and assurance.

The following eight principles form the core of the Sustainable Development Framework in mining sector in India.

1. Incorporating Environmental and Social Sensitivities in decisions on leases: It integrates sustainable development concepts at the earliest phase of the mining life cycle. The investors will assess the risks and then they will proceed.

2. Strategic Assessment in Key Mining regions: This principle allows understanding of mining activities occurs in clusters which have impacts at a regional level, undertake a strategic assessment of regional and cumulative impacts and develop a Regional Mineral Development Plan based on as assessment of the regional "capacity" at periodic intervals.

3. Managing impacts at the Mine level impact through sound management systems. The key elements of this principle are impact assessment of key environmental, social, health and safety issues, development of management framework and systems at the mine level and continual improvement of the same on the basis of international standards on a self driven basis. A key elements is disclosing performance on environmental and social parameters to external stakeholder at every stage of the project lifecycle;

4. Addressing Land, Resettlement and Other Social Impacts. This principle demands a comprehensive assessment of social impacts and displacement of mining projects at the household, community and mining region level, and management commitment to address those impacts through mitigation measures and management plans;

5. Community engagement, benefit sharing and contribution to socio-economic development. This principle seeks commitment to regular engagement with the local community as well as sharing of project benefits with the affected families. It is rooted in the principle of sharing profits with the affected communities already provisioned for the in draft MMDR Act awaiting approval. It dovetails the social impact management of project operations with the CSR initiatives being undertaken and looks at an integrated approach to mitigate impacts and improve local livelihoods and living conditions in the neighbourhood areas/communities.

6. Mine Closure and Post Closure Mining operations must prepare, manage and progressively work on a process for eventual mine closure. This process must cover all relevant aspects and impacts of closure in an integrated and multi-disciplinary way. This must be an auditable document and include a fully scoped and accurate estimate of planned cost of closure to the company. The cost estimates must be adequately provisioned to cover national, regional and local legal and regulatory requirements for closure; and must also include the cost of servicing all agreements/commitments made with stakeholders towards post-closure use;

7. Ethical functioning and responsible business practices. This principle underlines the need for ethical business practises and a strong sense of corporate responsibility among mining companies. It recommends companies to go beyond legal compliance; and

8. Assurance and Reporting. This principle seeks mining sector stakeholders to assess their performance against this SDF and demonstrate continual improvement on this performance over the life of the project. It requires this performance to be reported in a structured manner in a Sustainable Development Report to be disclosed in the public domain as well as to regulatory agencies to consider during approval processes (Ministry of Mines, May, 2012).

Despite having SDF, the institutional arrangement hardly succeeded to curb the illegal mining activities as such activities continued even after the SDF and being controlled by the mining regulators. It has been claimed that the SDF will provide guidance for the mining companies to improve performance on environmental and social aspects. The SDF will need to be used by mining companies to demonstrate commitment to sustainable development and requires submitting to the regulators when and at the time of seeking clearance or renewal or extension. It should also be used by regulators to evaluate the mining 
company's commitment to achieving environmental and social goals.

Some past Studies on Sustainable Conservation: Several studies and reports (Ministry of mines, 2012-2017) documented that exploration, development, production, and disposal of minerals not only affect the environment and ecology in mining areas, but also livelihood of the tribal people, living in backward regions and mining areas (Forest survey report, 2008) Lahiri-Dutt (2007) conducted survey of illegal coal mines in the eastern India and confirmed that they continued despite regulation. Zulu and Wilson (2012) the strict licensing policy in diamond mining in Sierra Leone drove many into illicit mining/trading. Strengthening anticorruption policies is demonstrably one of the keys to good natural resource management (Iimi, 2007). Natural resource depletion can destabilize livelihoods, negatively affecting ecosystems, and undermine peace and development (http://www.un.org). Exploitation of natural resources is a key factor in economic growth and development, and also one that can have serious negative environmental and socioeconomic impacts (Cronin and Pandya, 2009). Several studies (Working Group, $12^{\text {th }}$ Five Plan, TERI Study, etc.) documented impact of illegal mining on environment and people, but present institutional arrangement failed to halt depletion of resources and restore them wherever possible. "The greed of a few is making everyone suffer" (The Supreme Court of India, July 29, 2011). Ostrom (1990) and Bromley, (1992) argued that participation of people as local users' groups are capable of managing natural resources through collective action. Chambers \& McBeth (1992) also argued that the people's participatory model and the collective action conserved mother resources in very efficient way. Local community participation concept becomes model for the policy framers (Agrawal and Gibson, 1999).

The livelihood dependency of tribal population on forest resources is quite high and most of the mining are located in such areas only. Hence there is a serious question on land conversions on account of mining, due to the problems of rehabilitation and adaptation (Kadekodi, 2010). Even the Supreme Court of India in Samatha Judgement of 1997 (Samatha Vs State of Andhra Pradesh, 1997) ruled that mining in schedule V areas should not be allowed without the participation of the local people. While pronouncing the judgement, Judges laid down certain duties for entity that mine in scheduled areas as; (a) 20 per cent of net profits to be set aside as a permanent fund for the establishment and maintenances of water resources, schools, hospitals, sanitations, and transport facilities, reforestation, and maintenance of ecology among the others; (b) suggested to state governments to organise cooperative societies solely composed of Scheduled Tribes to undertake mining operation in those areas. However, the Government of Andhra Pradesh has given excuses for development of the state by occupying the tribal lands for mining activities without paying proper compensation and rights instead it tried to undermine the far-reaching directives on several times after 2000 .

In addition, mining activities has to be carried in a way that must have minimum damage to natural resources such as air, water, soil, and biomass. Forest (Conservation) Act, 1980 and Environment (Protection) Act, 1986 impose certain restrictions on prospective miners. It is clear in the Act and rules that clearances are required to ensure the conserve forests and protect the environment. The International Council of Mining and Metals (ICMM) and the World Conservation Union (International Union for the Conservation of Nature and Natural Resources) (IUCN) together has developed a SDF, comprising 'ten principles' of mining, a Global Reporting Initiative (GRI) to enable verification of the implementation those principles by miners across the world, and good practice guidelines in the form of a Mining and Metals Sector Supplement containing relevant indicators that will allow mining companies to track their performance against the ten principles and the GRI guidelines. However, SDF and its guidelines are hardly implemented.

\section{Conflicting Situation}

As envisaged by the Five Year Plan, higher economic growth and development remained top priority throughout all plans. But, economic growth achieved only by over-exploiting natural resources and displacing poor people, including tribals; however, real benefits have not reached to these deprived groups of people even today. For example, local tribal people resisted the mining project of the Bharat Aluminium Company (BALCO) in the

Environment Conservation Journal 
Gandhamardan Hills, which directly threat the survival of the people. Such conflicting situation continues in other parts of the country, where locals are displaced by opening mines in name of development of the areas. While opening mining sector to private players, the conservation of environment and biodiversity should be a top priority. But, evidences show that illegal mining without prior permission of the public authority continues in many parts of the country. The real benefits of illegal mining activities are reaped by private players in collusions with dishonest politicians and public officials at the cost society, which would pay for loss of valuable nonrenewable natural resources, over-exploited for private gains instead of public gain. Out of overexploitation of minerals and illegal mining, it has been alleged by reports that state exchequers run in losses in crores of rupees (billions of dollars). SDF designed in 2006, it seems, has no impact on the illegal mining. It is nothing but failure of institutional arrangement in the country. The Government always says about illegal mining and their controlling, but nothing happened (refer document of Ministry of Mines, Govt. of India, 2011). As complained by several people and acknowledging a large scale illegal mining by mining mafia without permission of public authority in various states, the Central Government has appointed Commission of Inquiry (Justice M.B. Shah Commission of Inquiry set up by Ministry of Mines in November 2010) look into the extent of illegal mining. The environmental degradation in the area was shocking. The state should bear the cost of restoring the area. "The greed of a few is making everyone suffer," (Supreme Court of India). The collective efforts or action has not been placed so far so that local would have better livelihoods instead Central Government as well as the Government of Andhra Pradesh tried their best to occupy the tribal lands on several occasions under the influence of mighty politicians and mining mafia, despite having constitutional safeguard for tribals in scheduled areas under scheduled V.

\section{Public vs. Private Wealth}

The trends are continuously increasing in developed and industrialized country to import raw materials like minerals from other developing countries, having abundant natural resource base, keeping own such resources intact for future consumption. For example, it seems that China and Japan are wisely preserving their own natural resources like ores for future consumption. At the same time, they meet their present requirement and needs by importing natural raw materials from India. The same principles are followed by the USA, European countries, etc. These countries preserve their natural resources for their future needs.

As the underground natural wealth regulated and owned by the Government of India and some extent by the state governments, the competition rose among the prospective private investors in mining sector for getting licences. Consequently, it gave birth to illegal transaction for obtaining licenses too. When it happens, there are more possibilities of violation of Environmental (Protection) Act 1986, Forest (Conservation) Act 1980, and Biodiversity Act 2002 etc. in the country. The scenario is same in every other state where powerful and well-connected private mining companies and related people monopolized their control over the mineral resources and irrationally extracting mineral wealth and accumulating wealth as much as they can do.

Free Rider Theory (Olson, 1965) suggests that individual or a group of individuals reap the benefits more than what they deserve for in way of their share in such public or community property and shoulder less a burden of responsibility of conserving or sustainable development of the same. In case of private mining investors in India, they become free riders and reap benefits without sharing responsibility even though there are well established regulations for such illegal activities, indicating weakness of governance. The public property becomes as a source of additional income to corrupt officials as well as to corrupt politicians. They become stronger since institutional arrangement fails to carry out its responsibility and so, the sustainable development of natural resources cannot be expected. In true sense, it is against the principles of sustainable development.

\section{Illegal Mining-A Case of OMC}

One of the cases came to limelight in recent time was of Obulapuram Mining Company (OMC). Under this deal, ministers were found to involve in illegal mining activities. OMC, has obtained mining license and leasing rights from his father. While renewing the lease area in 1984, the company has 
applied for 64.20 acres only (25.98 hectares) within the original lease area. However, company continued its activities, without demarcating the lease area, on original lease area. Dispute was settled on the decision of Hon'ble High Court of A.P., Hyderabad to surrender remaining area of 483.42 acres to the government. The company was allowed to continue its mining activities on sanctioned lease for a period of twenty years from 1984 to 2004, after obtaining clearance from Govt. of India. However, lease deed was actually executed on 26.04.1997. Since then, in subsequent year, the OMC has taken over several mining leases of Anantapur Mining Corporation, Y. Mahabaleswarappa \& sons etc., against the provisions of Mines and Minerals (Regulation \& Development) Act, 1957.

Though the lease was sanctioned for 64.20 acres only (25.98 hectares), the Indian Bureau of Mines (IBM) has permitted mining only in six hectares out of this land, allowing extracting only 7.50 lakh tonnes per year. Despite the limitation, the OMC has extracted more than 20 lakh tones of iron ore from lease area of 25.98 hectares in three years period. It seems that it could not have happened without illegal dealings. Another big jolt to the sustainable conservation of resources came from the Ministry of Environment and Forests (MoEF), GOI, which has given permission for this in the year 2007, without obtaining clearance from GOI under Forest Conservation Act and other statutes, indicating either favour to company or involvement of public authority in private economic gain. In fact, in prima facie, $\mathrm{OMC}$ has encroached the area beyond the allotted and permitted area for looting natural resources from un-allotted 10 hectares of forest land without permission of government and extracted million tonnes of iron ore, without paying royalty, shouldering any responsibility, and at the cost of environmental degradation, biodiversity loss etc. In fact, it fits for as an example of 'free rider' on public wealth.

Meanwhile, another important development happened that the State High Level Committee (Govt. Of Andhra Pradesh) conducted an enquiry on allegations made by the several people and reports for encroachment of mining land, the committee has rejected the theory of encroachment of forest land beyond the permitted lease area. Even though, the Ministry of Environment and Forest
(MoEF), GOI, vide its proceedings dated 22.04.2009, has intervened and directed the government of Andhra Pradesh to stop mining in all these leases and to take action against the officials for allowing mining without demarcation of boundaries on the ground, basing on the findings of the Forest Advisory Committee.

The Forest Advisory Committee has recommended for suspension of mining till demarcation is completed by Survey of India (and) till proper boundaries and safety zones are provided to these mines on ground. The MoEF, GOI directed that "permission given for five mines ......be kept in suspension with immediate effect till demarcation is completed by Survey of India..." and further directed "...to initiate action against officials for allowing the mining without proper demarcation on the ground". The Supreme Court of India also directed the Central Government to demarcate boundaries through survey of India; however, the Government of Andhra Pradesh tried to convince the Central Government to accept the report of the state government on disputed areas to cover up the illegal mining. Even though most of the issues have been discussed at various forums and some of the cases are filed before the Lokayukta and courts, the illegal activities of mining are still continuing. Justice Hegde, Lokayukta of Karnataka state, has documented in his second report, how state has suffered of revenue loss owing to illegal mining activities over four years (2006-2010) at Rs 16,085 crore. He has recommended that the amount be recovered from those who caused it - politicians, officials and companies. The report also seeks criminal action against three ministers - G Janardhana Reddy, G Karunakara Reddy and B Sriramulu.

\section{Who is Benefited?}

It is true that in Andhra Pradesh, Karnataka, Jharkhand and Orissa, some of the mining areas are allotted on lease to the private companies on nominal royalty rates. In fact, lease of such mining areas are given to the persons, who are very close to political parties, politicians and bureaucrats. It is shocking incidences happen that government level that bribe is common for obtaining lease. Otherwise, it is very difficult to obtain lease in mining sector in India. But, who will bear the extra burden of bribes? The fact is that such burden is passed on public exchequer at cost of losing 
revenue to the government. At the same, natural resource base degrades rapidly at a rate of more than the amount of bribes, which are recovered by exploiting additional natural resources. Such practices allow the illegal extract of mineral resources of public wealth for private gain. The act of dishonest politicians, and bureaucrats, who indulge the practices illegal activities, is also not less than the act of free riders, without shouldering any responsibility of degradation and loss. Such kind of nexus between politicians and mafia not only damage environment but also push the future generation in danger. The sustainable development concept (UN Report, 1992) suggests that state shall cooperate in a spirit of global partnership to conserve, protect and restore the health and integrity of the Earth's ecosystem (Principle-7). However, governance badly becomes inefficient to understand the importance of the natural resource and their sustainable development.

\section{Legal issue on Free Rider}

As discussed, it is clear that free riders never share the responsibility of degradation resources instead they reap benefits as maximum as they can do. The responsibility of management of natural resources with the Government, but it partially succeeded to conserve resources. There are many evidences that people opposed the action of government officials of favouring persons for private gain, but no action was taken or taken but they were eyewash only. On the contrary, there are success stories on managing public/community resources like community forest, fisheries and irrigation tanks etc., collectively managed natural resources better than the government machinery. For example, community forest in Nepal, Irrigation canal in Sri Lanka, Fishery in some countries helps to meet their local needs like employment and income generation at large scale and at the same time, managed to balance the environmental and biodiversity degradation.

As discussed above about OMC, which is private company in iron ore mining, has extracted iron ores from allotted and un-allotted lease areas. But, public authority failed to recover the loss, which caused by illegal mining activities. There is no chance of recovery of losses. Is it right way to conserve valuable natural resources? Will not put pressure on ecological imbalances? The documentary evidences show there lapses on the part of state governments (particularly Government of Andhra Pradesh and Government of Karnataka) and at central level, who monitors the management of natural resources. For example, despite established rules in the country, the mining areas are allotted to private companies without demarcating boundaries of working areas violates the sense of good governance practices. People voices oppose the irregularities, but their voices are either shut or forced to be shut by violators. If it is described in simple world, it is collective action of some self-interest dishonest public officials and mining mafia to make loss to public exchequer. For example, IBM has fixed limit to extract 7 million tonnes of iron ores per year by OMC, but OMC extracts 20 million tonnes per year. It accounts three times more than the limit. It means unsustainable extract of natural resources. If such practices continue for longer period, then it will last in less than one-third of total numbers of year for expected to be lasted.

The news from Orissa stated that the illegal mining activity, perpetrated by mining mafia in iron ore rich Keonjhar district, is causing a revenue loss of over Rs 200 crore to the state exchequer annually. The Goa State has similar kind of illegal mining; however, the central government has not taken action even after such activities are noticed. In Maharashtra state too, the entire Thane district has been denuded of sand over the years. Now the mining mafia is active in Navi Mumbai and Raigad district. The Bombay High Court banned, on September $24^{\text {th }} 2010$, sand extraction across Maharashtra, including those holding licenses, observing that the activity was damaging river beds and causing flood threats. All these incidences describe that Governments in respective state have unable to restrict illegal mining under law, indicating inefficiency of the governance. The Theory of Tragedy of Common (Garrett Hardin) came with some principles that how common man will have problem in future if the present generation does not use natural resources rationally. The natural resource depletion occurs as result of inadequately define the boundary of property rights, misuse of power by public authority, inadequate set legislations to regulate rights, nexus between public authority and private parties. Depleting resources by way of either irrational extract or illegal extract or over extracting minerals for today's use to make 
money negatively affects the requirement of future generation. The Collection Action (Olson, 1965) suggests that groups of individuals with common interests usually attempt to further those common interests. Groups of individuals with Common interests are expected to act on behalf of their personal interests. The groups act to serve their interests, presumably, is based upon the assumption that the individuals in groups act out of selfinterest. If the members of some group have a common interest or objective, and if they would all be better off if that objective were achieved, it has been thought to follow logically that the individuals in that group would, if they were rational and selfinterested, act to achieve that objective (Olson, 1965). This theory put common man in collective action for the betterment of the group, but, selfinterested dishonest public officials and mining mafia collectively act for private gain, instead of public gain. In such case, self-interest is stronger, which undermines collective action for public gain. If it is happing like this, public goods natural resources will be in danger. Already, it came to notice that mining increases surface run-off and decreases infiltration. The increased run-off combined with the choking of water courses with overburdens and fines are causing floods and droughts in regions-which had stable and perennial supplies of water (Shiva, 1991).

\section{Conclusions}

On appeals of various international agencies, developed countries turned to be rational users of their natural resources, but these countries are tirelessly searching new places and markets in developing countries. Consequently, competition of exploiting natural resources increased in developing country even through illegal mining activities to earn maximum gain and profit.

India also changed its mining policy in 2008. The private players in mining sector use their political connection and exploit mineral resources even illegally. It also encourages new relationship between politicians and mining mafia for over exploitation of minerals. The institution also fails to curb the illegal mining activities because of their strong nexus.

The local mining mafia stretched their empire for private gain at the cost of public resources, violating most of the environmental norms, biodiversity norms, and public health norms. On exposing such kind of illegal activities in mining areas, the political leadership is engaged to cover up such activities. Over-exploitation of minerals illegally not only affects the environment and ecology but also livelihood of the tribal people, those are living in backward regions and mining areas. The real benefits are reaped by private players at the cost society.

\section{Acknowledgment}

I am very much grateful to ICSSR, New Delhi for sponsoring the on-going project. This paper is the outcome of that ongoing project.

\section{References}

Forest Survey of India Report, 2008. According to the Forest Survey of India, the average forest cover in tribal districts of the country is 37 percent (Chandra Bhushan, 2008).

Agrawal, Anil, \& Gibson, C. 1999. Enchantment and disenchantment: The role of community in natural resource conservation, World Development, 27(4), 629-649.

Bromley, Daniel W. 1992. 'The Commons, Property, and Common-Property Regimes', in Bromley, Daniel W. et al. (eds), Making the Commons Work: Theory, Practice, and Policy, San Francisco, ICS Press, 3-15.

CEC. 2009. Central Empowered Committee Report (interim) in writ Petition (civil) no. 562 of 2009 filed by Samaj Parivartana Samudaya and Others regarding illegal mining and Other related activities in forest Areas of Karnataka.

Central Water Commission (CWC). 2006-07. Annual Report 2006-07, Govt of India.

Chambers, R. \& McBeth, M. K. 1992. Community encouragement: Returning to the basis for community development, Journal of Community Development Society, 23(2): 20-38.

Chandra Bhushan. 2008. Rich lands, poor people: the socioenvironmental challenges of mining in India, $6^{\text {th }}$ citizen's report.

Chandrasekhar, C P. 2010. Liberalising loot , Frontline, Volume 27 - Issue 14, Jul. 03-16.

Cronin, Richard and Amit Pandya, 2009. Exploiting Natural Resources: Growth, Instability, and Conflict in the Middle East and Asia, Washington, DC: The Henry L. Stimson Center.

Dasgupta, Partha. 2013. Green National Accounts in India A Framework, Ministry of Statistics and Programme Implementation Government of India. 


\section{Challenges of natural resources management in India}

Forty-second session, Agenda item 82 e, Resolutions adopted by the General Assembly, 42/187, Report of the World Commission on Environment and Development, A/RES/42/187, 11 December 1987. The report of the World Commission on Environment and Development: Our Common Future was published in 1987.

Govt. Of India. 2010. Lok sabha, The Commission, which would present its report within 18 months, would identify persons or firms responsible and ascertain if there had been any tampering of official records relating to land and boundaries. The Minister of State for Mines B K Handique has made statement in Loksabha on illegal mining, raising, transportation and export of iron ore and manganese ore illegally or without lawful authority in many states on a large scale," Handique said.

Ministry of Mines. 2008. National Mineral Policy, 2008, Govt. of India.

Ministry of Mines Report Govt. of India, 2010 -11. The Annual Report, 2010-11,

Ministry of Mines. May 2012. The report of the Committee for Review and Restructuring of the Functions and Role of IBM, Govt. of India, http://ibm.nic.in/index.php?c=pages\&m=index\&id=366.

Hardin, Garrett. 1968. The Tragedy of the Commons, Science, 162(1968):1243-1248.

Iimi, Atsushi, 2007. Escaping from the Resource Curse: Evidence from Botswana and the Rest of the World, IMF Staff Papers, Vol. 54, No. 4, pp. 663-699, Palgrave Macmillan Journals on behalf of the International Monetary Fund.

Kadekodi, Gopal, 2010. Mineral Extraction and Impact on Common Property Land Resources, Centre for MultiDisciplinary Development Research Dharwad-580004.

Lahiri-Dutt, Kuntala, 2007. Illegal coal Mining in Eastern India: Rethinking Legitimacy And Limits of Justice, Economic \& Political Weekly, December 8.

Ministry of Mines, Govt. of India. 2011. Report of Working Group On Mineral Exploration And Development (Other Than Coal \& Lignite) For The Xii Five Year Plan (201217)

North, Douglass C., 1990. Institutions, Institutional Change and Economic Performance. Cambridge University Press. ISBN 0521397340.
North, Douglass C., 1993. Economic Performance through Time. Lecture to the memory of Alfred Nobel. The Nobel Foundation. Retrieved November 14, 2008.

Olson, Mancur., 1965.The Logic of Collective Action: :Public Goods and the Theory of Groups. Cambridge: Harvard University Press.

Ostrom, Elinor., 1990. Governing the Commons: The Evolution of Institutions for Collective Action, New York, Cambridge University Press.

World Commission on Environment and Development Report. 1987. Forty-second session, Agenda item 82 e, Resolutions adopted by the General Assembly, 42/187, Report of the World Commission on Environment and Development, A/RES/42/187, 11 December 1987. The report of the World Commission on Environment and Development: Our Common Future was published in 1987.

Shiva, Vandana. 1991. Ecology and the Politics of Survival Conflicts Over Natural Resources in India, Sage Publications India Pvt Ltd, New Delhi.

Supreme Court of India. 1997. Samatha Vs. State of Andhra Pradesh, Case No.: Appeal (Civil) 4601-02 Of 1997, Date of Judgment: 11/07/1997.

The United Nations Conference on Environment and Development at Rio de Janeiro from 3 to 14 June 1992) reaffirmed the Declaration of the United Nations Conference on the Human Environment, adopted at Stockholm on 16 June 1972, and seeking to build upon it.

UN. 1972. Report of the United Nations Conference on the Human Environment, Stockholm, 5-16 June 1972 (United Nations publication, Sales No. E.73.II.A.14 and corrigendum), chap. I.

UN. 1992. Agenda-21- Report of the United Nations Conference on Environment and Development, (Rio de Janeiro, 3-14 June 1992)

Working group of $12^{\text {th }}$ Five Year Plan 2012-17. Ministry of Mines, Govt. of India; Vandana Shiva, TERI Environment Study, Supreme Court of India In Samatha Judgement of 1997.

Zulu Leo and Sigismond Wilson 2012. Whose Minerals, Whose Development? Rhetoric and Reality in PostConflict Sierra Leone, Development and Change, Vol. 43, issue (5): 1103-1131. 